\title{
Stakeholder Perception towards the Implementation of National Health Insurance Program
}

\author{
Yuli Susanti, ${ }^{1}$ Tita Barriah Siddiq, ${ }^{2}$ Siska Nia Irasanti, ${ }^{1}$ Rizki Perdana, ${ }^{3}$ Yusuf Heriady ${ }^{4}$ \\ ${ }^{1}$ Department of Public Health, Faculty of Medicine, Universitas Islam Bandung, Bandung, Indonesia, \\ ${ }^{2}$ Department of Medical Education, Bioethics, Humanities and Islamic Insert, Faculty of Medicine, \\ Universitas Islam Bandung, Bandung, Indonesia, ${ }^{3}$ Department of Anatomy, Faculty of Medicine, \\ Universitas Islam Bandung, Bandung, Indonesia, ${ }^{4}$ Department of Surgery, Faculty of Medicine, \\ Universitas Islam Bandung, Bandung, Indonesia
}

\begin{abstract}
Indonesian National Health Insurance (NHI) is a social protection program that ensures the fulfillment of basic needs for proper health by implementing a quality and cost control system. There are still differences in perceptions and complaints felt by patients regarding the implementation of the NHI program. The purpose of this study was to evaluate the implementation of the NHI program based on the perception of all stakeholders in the aspect of health equity, quality of service, and health financing. Quantitative research methods with survey techniques on 204 respondents were selected by stratified random sampling in Al-Ihsan Regional General Hospital West Java Province from January to May 2021. The data were analyzed by using the Kruskal-Wallis test and Mann-Whitney $\mathrm{U}$ test on the perception of the stakeholder groups. The results showed that the aspects of health equity, service quality, and health financing on the implementation of the NHI program were in a good category. The increase in Healthcare and Social Security Agency (HSSA) insurance premium was considered the lowest aspect. There were significant differences in the perception of stakeholder groups on the aspects of health equity, service quality, and health financing. There were significant differences in perceptions of health equity based on the ages groups and in perceptions of health financing based on income. This indicates that stakeholders' perceptions of the NHI program affected some conditions, including roles in services, ages, and income.
\end{abstract}

Keywords: National health insurance, perception, stakeholder

\section{Persepsi Stakeholder terhadap Implementasi Program Jaminan Kesehatan Nasional}

\begin{abstract}
Abstrak
Jaminan Kesehatan Nasional (JKN) merupakan program perlindungan sosial yang menjamin pemenuhan kebutuhan dasar kesehatan yang layak melalui penerapan sistem kendali mutu dan biaya. Masih terdapat perbedaan persepsi dan keluhan yang dirasakan pasien terhadap pelaksanaan program JKN. Tujuan penelitian ini mengevaluasi pelaksanaan program JKN berdasar atas persepsi seluruh stakeholder pada aspek health equity (pemerataan), mutu layanan, dan pembiayaan kesehatan. Metode penelitian kuantitatif dengan teknik survei pada 204 responden yang dipilih secara stratified random sampling di RSUD Al-Ihsan Provinsi Jawa Barat periode Januari-Mei 2021. Analisis data menggunakan Uji Kruskal-Wallis dan Mann-Whitney U terhadap persepsi kelompok stakeholder. Hasil penelitian menunjukkan bahwa aspek health equity, mutu layanan, dan pembiayaan kesehatan pada implementasi program JKN berada dalam kategori baik. Kenaikan premi asuransi BPJS Kesehatan dinilai paling rendah. Terdapat perbedaan signifikan persepsi antara kelompok stakeholder pada aspek health equity, mutu layanan, dan pembiayaan kesehatan. Terdapat perbedaan signifikan persepsi terhadap health equity berdasar atas kelompok usia dan persepsi pada aspek pembiayaan kesehatan berdasar atas pendapatan. Hal ini menunjukkan bahwa persepsi stakeholder terhadap program JKN dipengaruhi beberapa kondisi, antara lain peran dalam layanan, usia, dan pendapatan.
\end{abstract}

Kata kunci: Jaminan kesehatan nasional, persepsi, stakeholder

Received: 3 June 2021; Revised: 7 August 2021; Accepted: 11 August 2021; Published: 31 August 2021

Correspondence: Yuli Susanti, dr., M.M. Department of Public Health, Faculty of Medicine, Universitas Islam Bandung.

Jln. Tamansari No.22, Bandung 40116, West Java, Indonesia. E-mail: yulisusantiarmandha@gmail.com 


\section{Introduction}

Universal health coverage (UHC) implies that all people have access to quality health services without worrying or experiencing difficulties paying for health care. Health equity can only be achieved if each individual has the opportunity to maintain his/her health potential. ${ }^{1}$ The National Social Security System or Sistem Jaminan Sosial Nasional (SJSN) is a program of the Indonesian Government to assure social protection and welfare for all people. ${ }^{2}$

Jaminan Kesehatan Nasional (JKN) or the National Health Insurance (NHI) program is part of the SJSN to provide insurance in the health sector. The implementation of the NHI program using the principles of managed care is a technique that uses an integrated approach and the financing of health services through quality control and cost control by increasing the feasibility and efficiency of health services. ${ }^{3,4}$

One of the main objectives of the NHI program is to improve equity in access to health services. Several previous studies prove that health insurance has a positive impact on improving access to health care..$^{5-7}$ The NHI program has an impact of $2.4 \%$ on access to inpatient care at the hospital. ${ }^{6}$ The broader the participation of NHI so participants can more widely use the benefits package guaranteed by NHI. Optimization of healthcare utilization by participants must be supported by the equitable distribution of health facilities and personnel. ${ }^{8}$

The implementation of a quality control system for health insurance services must be carried out comprehensively, including meeting the quality standards of health facilities, ensuring that the health service process runs according to established standards, and monitoring participants' health outcomes. ${ }^{9}$

The high number of referrals to advanced health services (hospitals) increases health costs, which burden the Government's budget. Furthermore, they are not following the quality control and cost control principles implemented by Badan Penyelenggara Jaminan Sosial Kesehatan (BPJS Kesehatan) or the Healthcare and Social Security Agency (HSSA). The HSSA underwent a deficit in health financing during six years of program implementation because of the premium below an actuary cost. ${ }^{10}$

The inequalities of HSSA's tariff than the actual cost issued of health services indicate that the NHI program's implementation in the funding aspect is not run optimally. ${ }^{11,12}$ At the primary level of service, the doctor's perception about the NHI program has been informed. However, there is still a complaint about the socialization of the program and capitation late payment. ${ }^{13}$

Perception is a process related to the entry of messages or information into the human brain, through human perception continuously in contact with the environment. This connection is carried out through sight, listener, touch, taste, and smell. ${ }^{13}$ Problems that arise in health services can be caused by a lack of information and differences in perceptions among stakeholders in implementing the NHI program.

There are different perceptions between the premium receiver and the non-receiver based on the provision of information implementation and pay the benefits or HSSA health services finance in Sleman. ${ }^{14}$ Another problem arises from health workers both at the hospital and primary health facilities. There are $47.6 \%$ of specialist doctors felt that they were not satisfied with the NHI program, and there is the relationship between satisfaction with Indonesian Case-Based Groups (INA-CBGs) knowledge, the work environment, remuneration, transparency, and hospital policy at dr. Zainoel Abidin Regional General Hospital. ${ }^{15}$

Health service management consists of at least three groups of people involved. First is the human health service provider (health providers, for example, doctors, nurses), Second, the health service recipient group (consumers), and the third group, who are indirectly involved, are the administrator (both among companies and governments and others). ${ }^{16}$

The purpose of this study was to analyze the difference of perception between stakeholders who play a role in the implementation of the NHI program in hospitals within three aspects; equity of health, quality of service, and health financing. The stakeholders are health providers or health workers, hospital management, employees, patients, and the team of HSSA. The results of the study can be used for the improvement of the NHI program in the future.

\section{Methods}

This study used quantitative methods with a cross-sectional design-a survey used to gather data. The questionnaire consisted of 33 questions to assess three aspects of the implementation 
Table 1 Questionnaire Dimensions

\begin{tabular}{|c|c|c|}
\hline Variables & & Statement Items \\
\hline \multicolumn{3}{|l|}{ Equity (equalization) } \\
\hline $\begin{array}{l}\text { Availability of health } \\
\text { facilities }\end{array}$ & 2 & $\begin{array}{l}\text { In your opinion, are medical facilities (such as the number of inpatient rooms, } \\
\text { operating rooms, medical equipment, and laboratories) fully available in this } \\
\text { hospital? } \\
\text { Are non-medical facilities (such as parking lots, prayer rooms, canteens, waiting } \\
\text { rooms, breastfeeding rooms, and toilets) available in full at the hospital? } \\
\text { Does the hospital have sufficient supporting examination facilities/equipment (such } \\
\text { as laboratories, radiology, physiotherapy, and pharmacies). }\end{array}$ \\
\hline $\begin{array}{l}\text { Number of health } \\
\text { workers/human } \\
\text { resources }\end{array}$ & $\begin{array}{l}4 \\
5 \\
6\end{array}$ & $\begin{array}{l}\text { Does the hospital have a sufficient number of doctors/specialists for health services } \\
\text { Does the hospital have sufficient number of health personnel (nurses, pharmacists, } \\
\text { radiographers, analysts, and nutrition officers) for services? } \\
\text { Does the hospital have sufficient number of non-medical employees (security guard, } \\
\text { administration officer, customer service, and cleaning service)? }\end{array}$ \\
\hline Ease of access & $\begin{array}{l}7 \\
8 \\
9\end{array}$ & $\begin{array}{l}\text { Is the location of the hospital easily accessible/reachable (strategic)? } \\
\text { In your opinion, is registration at the hospital easy to do? } \\
\text { In your opinion, is information about the doctor's schedule and types of services at } \\
\text { the hospital easy to obtain? }\end{array}$ \\
\hline $\begin{array}{l}\text { Medical service } \\
\text { development (within } \\
\text { the past year) }\end{array}$ & $\begin{array}{l}10 \\
11 \\
12\end{array}$ & $\begin{array}{l}\text { Did the hospital open a new polyclinic for service development in the past year } \\
\text { Did the hospital have a new type of service for service development in the past year } \\
\text { Did the hospital have additional supporting equipment/new medical examinations }\end{array}$ \\
\hline \multicolumn{3}{|l|}{ Quality of service } \\
\hline Reliability & $\begin{array}{l}13 \\
14 \\
15\end{array}$ & $\begin{array}{l}\text { Does the hospital have a reliable doctor/specialist in medical services? } \\
\text { Does the hospital have health workers (nurses/midwives/analysts/nutritionists) who } \\
\text { are reliable in non-medical services? } \\
\text { Does the hospital have employees who are reliable in non-medical services (security, } \\
\text { registration, customer service, cleaning service, billing) }\end{array}$ \\
\hline Responsiveness & $\begin{array}{l}16 \\
17 \\
18\end{array}$ & $\begin{array}{l}\text { Are the medical personnel (doctors/nurses) and hospital employees quick to respond } \\
\text { in handling patient complaints? } \\
\text { In your opinion, has the time to wait for service in the hospital met your } \\
\text { expectations? } \\
\text { Are the administrative services at the hospital are implemented quickly? (payment/ } \\
\text { cashier) }\end{array}$ \\
\hline Assurance & $\begin{array}{l}19 \\
20 \\
21\end{array}$ & $\begin{array}{l}\text { Are you sure about the medical services at this hospital? } \\
\text { Are you sure about the effectiveness of the treatment given by medical personnel? } \\
\text { Do medical and non-medical services in hospitals comply with the hospital minimum } \\
\text { service standards for the NHI program? }\end{array}$ \\
\hline Tangible & $\begin{array}{l}22 \\
23 \\
24\end{array}$ & $\begin{array}{l}\text { Does the area/place for medical services in the hospital meet your expectations? } \\
\text { Have the non-medical facilities at the hospital (parking area, prayer room, canteen, } \\
\text { waiting room, park) met your expectations? } \\
\text { Has the hospital's medical equipment met your expectations? }\end{array}$ \\
\hline Empathy & $\begin{array}{l}25 \\
26 \\
27\end{array}$ & $\begin{array}{l}\text { Are the doctors at the hospital able to understand the condition that the patient feels/ } \\
\text { empathize with? } \\
\text { Are the health workers (nurses/midwives) at the hospital able to understand the } \\
\text { patient's condition/empathy? } \\
\text { Are the hospital employees able to understand the patient's/empathetic condition? }\end{array}$ \\
\hline \multicolumn{3}{|l|}{ Health financing } \\
\hline $\begin{array}{l}\text { Increase in HSSA } \\
\text { premiums \& health } \\
\text { financing deficit }\end{array}$ & $\begin{array}{l}28 \\
29\end{array}$ & $\begin{array}{l}\text { Do you agree with the increase in HSSA contributions? } \\
\text { Can the increase in HSSA insurance premium contributions help the health financing } \\
\text { deficit experienced by HSSA? }\end{array}$ \\
\hline Clinical pathway & 30 & $\begin{array}{l}\text { Is the tariff for health services (according to the class in the hospital) in accordance } \\
\text { with the benefits you get? } \\
\text { Are Tariff adjustments/changes required for the HSSA service package? }\end{array}$ \\
\hline $\begin{array}{l}\text { Participant } \\
\text { compliance }\end{array}$ & 32 & $\begin{array}{l}\text { Do the compliance with payment of the HSSA participant contributions every month } \\
\text { need to be implemented? } \\
\text { Is it necessary to disseminate information about the benefits and compliance with the } \\
\text { payment of the HSSA participant? }\end{array}$ \\
\hline
\end{tabular}


of the NHI program. They are equity of health, quality of service, and health fund.

The questionnaire in this study consisted of three parts. The first part was screening questions that explain the study's objectives and classify respondents' consent about participation in the study. The second part contained the respondent's identity, and the third part included a list of questions regarding the study's variables, namely equity, quality of service, and health financing. The questionnaire used in this study can be seen in Table 1.

An instrument in this study has been undergone a validity and reliability test. The validity test was determined using the correlation Pearson product-moment according to the ordinal data scale. The item is valid if the critical $\mathrm{r}$ value $>\mathrm{r}$ table value $(0.361)$. The reliability test uses the method Cronbach alpha. A constructor variable is reliable if the coefficient reliability value is $>0.60 . .^{17}$

Data collection was carried out on stakeholders involved in implementing the NHI program at Al-Ihsan Regional General Hospital West Java Province, namely groups of doctors/specialists, patients, hospital management, nurses, midwives, hospital employees, and the HSSA team, from January to May 2021. Respondents were selected using a stratified random sampling technique with a total of 204 respondents, with the distribution of stakeholder groups as shown in Table 2. The samples met the inclusion criteria: 1. HSSA participants, 2. have used HSSA services at Al-Ihsan Regional General Hospital West Java Province, 3. aged 18-67 years, and 4. can read and access google forms via smartphone. Respondent profile that met the inclusion criteria can be seen in Table 3.

The assessment used the five-point Likert response format (ranging from $5=$ very good to $1=$ very bad). First, data analysis in this study was univariate to provide an overview of the

\section{Table 2 Stakeholder Group}

\begin{tabular}{clcc}
\hline No. & Stakeholders & n=204 & \% \\
\hline 1 & Doctor/specialist doctor & 34 & 16.7 \\
2 & Patient & 53 & 26.0 \\
3 & Nurse/midwife & 60 & 29.4 \\
4 & Hospital employees & 48 & 23.5 \\
5 & Hospital management & 5 & 2.5 \\
6 & HSSA team & 4 & 2.0 \\
\hline
\end{tabular}

Table 3 Characteristics of Respondents

\begin{tabular}{lrr}
\hline Variables & n=204 & \% \\
\hline Age (years) & & \\
25 & 13 & 6.4 \\
$26-35$ & 79 & 38.7 \\
$36-45$ & 53 & 26.0 \\
$46-55$ & 39 & 19.1 \\
$56-65$ & 16 & 7.8 \\
$>65$ & 4 & 2.0 \\
Gender & & \\
$\quad$ Man & 70 & 34.3 \\
$\quad$ Woman & 134 & 65.7 \\
Profession & & \\
$\quad$ Housewife & 30 & 14.7 \\
Civil servants & 36 & 17.6 \\
$\quad$ Private employees & 118 & 57.9 \\
Entrepreneur & 2 & 1.0 \\
Others & 15 & 7.4 \\
$\quad$ Not yet working & 3 & 1.5 \\
Education & & \\
$\quad$ Elementary school & 7 & 3.4 \\
Junior high school & 11 & 5.4 \\
Senior high school & 28 & 13.7 \\
Higher education & 158 & 77.5 \\
$\quad$ (diploma/bachelor/ & & \\
$\quad$ magister/doctoral) & & \\
Income & \\
$\quad<$ regional minimum & & \\
$\quad$ wages & 50 & 24.5 \\
>regional minimum & 154 & 75.5 \\
$\quad$ wages & & \\
\hline$\quad$ & & \\
\hline
\end{tabular}

perceptions of each stakeholder towards the study's variables, namely health equity, quality of service, and health financing. After that, the data was followed by bivariate analysis using the Kruskal-Wallis test to evaluate differences of perception between six stakeholder groups towards implementing the NHI program and the Mann-Whitney U test to evaluate the perceptual difference in two groups of respondent profiles.

This study had been approved by the Health Research Ethics Committee of the Universitas Islam Bandung, Indonesia, by issuing the ethical clearance number: 107/KEPK-Unisba/XII/2020.

\section{Results}

Table 4 showed that stakeholders perceived or assessed the health equity in the range of the good category (3.4-4.19). The number of health workers/human resources (HR) dimension is the lowest score in the health equity variable compare 
Table 4 Stakeholders Perception

\begin{tabular}{|c|c|c|c|c|c|c|c|c|c|}
\hline \multirow[b]{2}{*}{ Variables } & \multirow[b]{2}{*}{ Dimensions } & \multicolumn{6}{|c|}{ Stakeholders Perception } & \multirow[b]{2}{*}{$\begin{array}{l}\text { Total } \\
\text { Score }\end{array}$} & \multirow[b]{2}{*}{ Results } \\
\hline & & $\begin{array}{c}\text { Doctor/ } \\
\text { Specialist }\end{array}$ & $\begin{array}{c}\text { Hospital } \\
\text { Employees }\end{array}$ & $\begin{array}{c}\text { Hospital } \\
\text { Management }\end{array}$ & Patient & $\begin{array}{c}\text { Nurse/ } \\
\text { Midwife }\end{array}$ & $\begin{array}{l}\text { HSSA } \\
\text { Team }\end{array}$ & & \\
\hline \multirow[t]{4}{*}{ Equity } & $\begin{array}{l}\text { Availability of } \\
\text { health facilities }\end{array}$ & 3.95 & 4.29 & 4.73 & 4.06 & 4.38 & $3.5^{8}$ & 4.17 & Good \\
\hline & $\begin{array}{l}\text { Number of health } \\
\text { workers/HR }\end{array}$ & 3.92 & 4.11 & 4.20 & 3.72 & 4.18 & 4.00 & 4.02 & Good \\
\hline & Ease of access & $3 \cdot 74$ & 4.19 & 4.73 & 3.99 & 4.09 & 4.25 & 4.17 & Good \\
\hline & $\begin{array}{l}\text { Medical service } \\
\text { development } \\
\text { (within the past } \\
\text { year) }\end{array}$ & 3.94 & 4.24 & 4.87 & 3.95 & $4 \cdot 33$ & 3.67 & 4.17 & Good \\
\hline \multirow{5}{*}{$\begin{array}{l}\text { Quality of } \\
\text { service }\end{array}$} & Reliability & 3.90 & 4.26 & 4.80 & 4.12 & 4.43 & 3.75 & 4.21 & Very good \\
\hline & Responsiveness & 3.51 & 3.96 & 4.47 & 3.57 & 3.92 & $3 \cdot 33$ & 3.79 & Good \\
\hline & Assurance & 4.07 & 4.25 & 4.93 & 4.07 & $4 \cdot 37$ & 4.25 & 4.32 & Very good \\
\hline & Tangible & 3.66 & 4.13 & 4.33 & 3.75 & 4.10 & 4.00 & 4.00 & Good \\
\hline & Empathy & 3.88 & 4.15 & 5.00 & 3.90 & 4.22 & $4 \cdot 5^{8}$ & 4.29 & Very good \\
\hline \multirow[t]{3}{*}{$\begin{array}{l}\text { Health } \\
\text { financing }\end{array}$} & $\begin{array}{l}\text { Increase in HSSA } \\
\text { premiums and } \\
\text { health financing } \\
\text { deficit }\end{array}$ & 2.93 & 2.81 & 1.90 & 2.60 & 2.96 & 1.38 & 2.43 & Poor \\
\hline & Clinical pathway & 3.62 & 3.91 & 3.40 & 3.46 & 3.80 & 3.63 & 3.64 & Good \\
\hline & $\begin{array}{l}\text { Participant } \\
\text { compliance }\end{array}$ & 4.55 & 4.67 & 4.90 & 4.17 & 4.57 & $4 \cdot 38$ & 4.54 & Very good \\
\hline
\end{tabular}

Note: bad=1.0-1.79; poor=1.8-2.59; fair=2.6-3.39; good=3.4-4.19; very good=4.2-5.0

to the other dimensions but still in the good category (score 4.02). Average assessment of all stakeholders perceiving service quality variables in the good category, the responsiveness are the lowest score dimension in service quality variable (score 3.79). The health financing variable was assessed in the range of good category. However, the dimension of increased HSSA premiums and health financing deficit was the lowest score (2.43) with the poor category.

Statistical test was intended to analyze differences in perceptions between the six groups of stakeholders in assessing the implementation of the NHI program (Table 5). The hospital management group showed the highest perception toward the aspect of health equity, then nurses/midwives and by employees. Meanwhile, doctors, patients, and the HSSA team have a lower average perception value than other stakeholders. The results of the Kruskal-Wallis test showed a $\mathrm{p}$ value of 0.000 less than 0.05 , meaning that there was a significant difference in perceptions toward the implementation of the NHI in terms of health equity as seen by six stakeholders.

The average value of perceptions of service quality from the six stakeholders had different values, which the highest perception is shown by hospital management, nurses/midwives, and employees. Meanwhile, doctors, patients, and the HSSA team had a lower average perception value than other stakeholders. The KruskalWallis test showed a $p$ value of o.ooo less than 0.05. It means there was a significant difference in the perception of the implementation of the NHI in terms of service quality as seen by six stakeholders.

The highest stakeholder perceptions toward health financing were shown by doctors, employees, and nurses/midwives. Meanwhile, patients and the HSSA team had a lower average perception score compared to other stakeholders from the hospital management. The results of the Kruskal-Wallis test showed a p value of 0.002 less than 0.05 , meaning that there was a significant difference in perceptions of the implementation of the NHI in terms of health financing based on six stakeholders.

The respondent profile showed there were significant differences in perceptions of health equity based on ages ( $p$ value< $<.05$ ). There was no significant difference in perceptions of service quality based on ages, gender, education, and income ( $p$ value>0.05). There was a significant difference in perception based on income ( $p$ value<0.05). Stakeholders with income more 
Table 5 Statistical Test Result

\begin{tabular}{|c|c|c|c|}
\hline \multirow{3}{*}{ Stakeholders } & \multicolumn{3}{|c|}{ Implementation of NHI } \\
\hline & Health Equity & Quality of Service & Health Financing \\
\hline & $\mathbf{X} \pm \mathbf{S D}$ & $\mathbf{X} \pm \mathbf{S D}$ & $\mathbf{X} \pm \mathbf{S D}$ \\
\hline \multicolumn{4}{|l|}{ Groups } \\
\hline Doctors & $46.7 \pm 6.1$ & $57.1 \pm 8.9$ & $22.2 \pm 3.8$ \\
\hline Hospital employees & $50.5 \pm 6.5$ & $62.2 \pm 9.1$ & $22.8 \pm 3.5$ \\
\hline Hospital management & $55.6 \pm 2.7$ & $70.6 \pm 2.9$ & $20.4 \pm 4.7$ \\
\hline Patients & $47.2 \pm 7.4$ & $58.2 \pm 9.6$ & $20.4 \pm 3.6$ \\
\hline Nurses/midwives & $50.9 \pm 5.9$ & $63.2 \pm 8.1$ & $22.7 \pm 3.1$ \\
\hline HSSA team & $46.5 \pm 7.6$ & $59.8 \pm 17.6$ & $18.8 \pm 0.5$ \\
\hline $\mathrm{p}$ value ${ }^{\mathrm{a}}$ & 0.000 & 0.000 & 0.002 \\
\hline \multicolumn{4}{|l|}{ Age (years) } \\
\hline 25 & $49.8 \pm 5.5$ & $60.5 \pm 6.2$ & $22.5 \pm 2.5$ \\
\hline $26-35$ & $50.6 \pm 6.5$ & $62.5 \pm 9.3$ & $22.4 \pm 3.6$ \\
\hline $36-45$ & $49.7 \pm 5 \cdot 7$ & $60.2 \pm 9.2$ & $21.7 \pm 4.0$ \\
\hline $46-55$ & $48.4 \pm 8.1$ & $60.3 \pm 10.3$ & $21.3 \pm 3.6$ \\
\hline $56-65$ & $44.5 \pm 6.9$ & $57.8 \pm 8.1$ & $21.0 \pm 2.6$ \\
\hline$>65$ & $45 \cdot 4 \pm 7.1$ & $53.6 \pm 13.9$ & $21.6 \pm 4.9$ \\
\hline $\mathrm{p}$ value ${ }^{\mathrm{a}}$ & 0.026 & 0.194 & 0.459 \\
\hline \multicolumn{4}{|l|}{ Gender } \\
\hline Man & $48.1 \pm 7.6$ & $59.9 \pm 10.8$ & $21.2 \pm 3.8$ \\
\hline Woman & $49.7 \pm 6.2$ & $61.2 \pm 8.6$ & $22.3 \pm 3.4$ \\
\hline $\mathrm{p}$ value $\mathrm{e}^{\mathrm{b}}$ & 0.149 & 0.696 & 0.057 \\
\hline \multicolumn{4}{|l|}{ Education } \\
\hline Elementary school & $47.7 \pm 11.8$ & $62.7 \pm 12.5$ & $21.9 \pm 4.4$ \\
\hline Junior high school & $47.6 \pm 6.4$ & $59 \cdot 3 \pm 6.3$ & $21.4 \pm 2.5$ \\
\hline Senior high school & $47 \cdot 5 \pm 8.2$ & $58.3 \pm 10.5$ & $20.4 \pm 3.3$ \\
\hline Higher education & $49.6 \pm 6.2$ & $61.2 \pm 9.2$ & $22.2 \pm 3.6$ \\
\hline $\mathrm{p}$ value ${ }^{\mathrm{a}}$ & 0.368 & 0.406 & 0.072 \\
\hline \multicolumn{4}{|l|}{ Income } \\
\hline$<$ regional minimum wages & $48.0 \pm 7.7$ & $58.7 \pm 11.0$ & $20.7 \pm 3.9$ \\
\hline$\geq$ regional minimum wages & $49.6 \pm 6.4$ & $61.4 \pm 8.8$ & $22.3 \pm 3.4$ \\
\hline $\mathrm{p}$ value ${ }^{\mathrm{b}}$ & 0.120 & 0.113 & 0.015 \\
\hline
\end{tabular}

Note: ${ }^{a}$ Kruskal-Wallis test, ${ }^{b}$ Mann-Whitney test

than minimum regional wages have better perceptions of the health financing aspect than lower wages.

\section{Discussion}

The aspect of health equity was divided into four dimensions: the availability of facilities, the number of HR both health workers and supporting personnel, ease of access, and development of medical services. The service quality aspect was divided into five dimensions: reliability, responsiveness, assurance, tangible, and empathy. Finally, the health financing aspect was divided into three dimensions: the increase in HSSA premiums and health financing deficits, clinical pathways, and participant compliance. Based on the evaluation of stakeholders' perception shown in Table 4, aspects of health equity were in a good category. The dimension of the availability of human resources was assessed as lower than the other dimensions but still in the good category (score 4.02)-other dimensions such as the availability of facilities, accessibility, and development services to assess equalization health.

The majority of stakeholders agree that access to health services in the hospital was easy, and the hospital provides medical and non-medical facilities to support health services. The hospital is a referral hospital province with 450 beds with different classes of care. Also, it has flagship 
services, namely integrated cancer services, diabetic center, cardiac center, and supporting diagnostic radiology. ${ }^{18}$ This is consistent with several studies showing that the NHI program has been able to improve equitable access to health services which can be seen from the increasing number of NHI participants, where previously many people with low income and are vulnerable to have less access than a middle-class society with high income.7,19

The supply aspect plays a role in improving access to healthcare. The optimization of healthcare utilization must be supported by the equitable distribution of health facilities and personnel. ${ }^{8}$ Provision of health facilities is the obligation of the local and central government. It emphasized in Presidential Regulation No. 82 of 2018 concerning the obligations of the central and local governments in providing health facilities and infrastructure as an effort to meet the medical needs of the NHI participants. ${ }^{19,20}$

The adequacy of medical personnel in order to support healthcare was optimal. However, the number of health workers/HR was lower than the other dimensions on the health equity variable but still in the good category. The hospital has 607 health workers consisting of doctors/specialists, nurses, and midwives. ${ }^{18}$ The ratio of health workers per population in West Java Province has exceeded the World Health Organization (WHO) standard, such as 1:11 to a general practitioner and 1:77 to nurse. ${ }^{21}$

The health insurance benefits for the NHI participants are individual health services. They include promotive, preventive, curative, and rehabilitative services, including drug services, medical devices, and medical consumables following medical needs. It can be said that the health service benefits package guaranteed by the NHI program fulfills the basic needs of health services. The number of health facilities that cooperate with the HSSA is quite a lot. ${ }^{10}$

Increased access must also be followed by improving the quality of service. The availability and distribution of health facilities and human resources can affect the quality of services. This study assessed service quality based on five dimensions, reliability, responsiveness, assurance, tangible, and empathy. The assessment of stakeholder perceptions shown in Table 4 showed that the service quality aspect was in a good category.

Stakeholders assessed using the three dimensions of service quality, reliability, assurance, and empathy showed the very good category. The responsiveness has a lower score than the other dimensions. However, they are still in the good category. The responsiveness is associated with the speed of services and waiting time for administrative and medical treatment. The perception of stakeholders in the patient groups gave a low score on the waiting time of services in a hospital. According to other studies, the increase in HSSA participants impacted the number of patient visits to hospitals, resulting in a longer waiting time for services.. ${ }^{22,23}$ The importance to create a strong relationship between patients and hospital personnel and the need for hospital staff to be responsive, credible, and empathetic when dealing with the patients. ${ }^{24}$

The concept of affordable health facilities can be seen from the cost side. In this case, the NHI has provided medical expenses for participants who require health services. ${ }^{25}$ The NHI program was run by the social insurance mechanism for six years of its implementation. The HSSA, as the institution designated to deliver the NHI program, always experience a deficit. The deficit amount is increasing every year. The discussions among academic forums always state that the amount of HSSA contributions set by the government from 2014 to 2020 is underpriced as the root of the deficit problem. ${ }^{10}$

The process of health services cannot be separated from health financing. Health costs are the number of funds provided to organize and or utilize various health efforts required by individuals, families, groups, and communities. The mismatch of HSSA rates compared to the real costs incurred in health services indicated that the implementation of NHI in the financing aspect has not been running optimally..$^{10-12}$

The assessment of stakeholder perceptions toward implementing the NHI program in health financing was in a good category. However, stakeholders rated the lowest on the dimensions of the increase in HSSA insurance premiums. In addition, stakeholders assessed that the benefit packages received by participants were following the payments made. All stakeholders agreed that participant compliance was required to pay HSSA insurance premiums so that the NHI program does not experience a deficit in its implementation. Most of the stakeholders in this study $(75.5 \%)$ have income more than regional minimum wages, and most of them are hospital employees that have insurance from the office.

The Government and Local Governments 
have not established a mechanism to impose sanctions for non-compliance in paying HSSA contributions, especially for PBPU participants who register independently. As a result, many segments of PBPU participants tend to take advantage of NHI when they need it, and after that, they wait to pay their dues regularly. ${ }^{10,12}$

Based on the statistical test result shown in Table 5. There were still differences in perception among the six stakeholder groups for implementing the NHI program in the hospital. The hospital management groups, nurses/ midwives, and hospital employees gave the highest perception toward the aspect equity of health and service quality. This is because the hospital management and employee group have more contact with administrative, governance, and managerial activity, so they have better perceptions of equity of health and service quality. Whereas the nurses/midwives group, besides having duty on patient care, also have other duties to manage administrative for inpatient and outpatient.

The highest stakeholder perceptions toward the health financing aspect were shown by doctors, employees, and nurses/midwives. This is because the group of health workers provides health services directly to the patients, and not all the health services into the benefits package that HSSA insurance covers, so they gave a better perception of the health financing aspect. ${ }^{26}$

Perception is a process related to the entry of messages or information into the human brain, through human perception continuously in contact with the environment. ${ }^{13}$ Processing sensory information and relating to past experiences enables one to create a lens in which to view the world through a filter of sociocultural influences. ${ }^{27}$ There are the factors that influence and contribute to determining the perception. This factor includes functional or personal factors and structural factors. ${ }^{28}$

Based on the respondent profile, there were significant differences in perceptions of health equity based on ages ( $p$ value<0.05), and the adult group (ages 25-45 years old) has better perception. The administrative process and development of information technology such as enrollment online are more comprehensible for the adult group. Personal factors that influence the perception consist of the needs, experiences, past, motivations, hopes, desires, attention, emotions, values, memory, and mood. ${ }^{28}$

There were no significant differences in perceptions of service quality based on ages, gender, education, and income ( $p$ value>0.05). This showed that HSSA had provided health services equally without differentiating patients based on the class of service. It follows the mandate of the law and the NHI principle to provide fair and equitable health services.,29

There was a significant difference in perception based on income ( $p$ value<0.05). Stakeholders with income more than minimum regional wages have a better perception of the health financing aspect. It is in line with the theory that status, needs, and conditions influence perception. Higher-status people can exert influence on perception than low-status people. ${ }^{30}$

The statistical test result showed significant differences between the perception of the six stakeholder groups in assessing the implementation of the NHI program at Al-Ihsan Regional General Hospital West Java Province on health equity, service quality, and health financing. Thus, even though the health equity, service quality, and health financing aspects studied have been running well, they still have opportunities for improvement. Therefore, none of the three aspects are included in the very good/ satisfying category.

\section{Conclusions}

The results showed that the stakeholder's perception towards implementation of the NHI program was in a good category in health equity, service quality, and health financing. The increase in HSSA insurance premiums as the lowest dimensions should focus on attention that must be solved without increasing HSSA insurance premiums. The differences in perceptions on groups of stakeholders towards the implementation of the NHI program could cause problems if not handled properly. It is still needed to conduct socialization and cooperation of all stakeholders to make the service and utilization of the NHI program run optimally for mutual interest.

\section{Conflict of Interest}

No conflict of interest.

\section{References}

1. World Health Organization. Universal health coverage: moving towards better health: 
action framework for the Western Pacific Region. Geneva: World Health Organization; 2016.

2. Undang-Undang Republik Indonesia Nomor 40 Tahun 2004 tentang Sistem Jaminan Sosial Nasional.

3. Badan Penyelenggara Jaminan Sosial Kesehatan. Ringkasan eksekutif laporan pengelolaan program dan laporan keuangan jaminan sosial kesehatan tahun 2016 [Internet]. Jakarta: Badan Penyelenggara Jaminan Sosial Kesehatan; 2018 March 2 [cited 2021 May 30]. Available from: https:// bpjs-kesehatan.go.id/bpjs/arsip/view/951.

4. Suhanda R. Jaminan kesehatan dan managed care. JKS. 2015;15(2):104-13.

5. Sparrow R, Suryahadi A, Widyanti W. Social health insurance for the poor: targeting and impact of Indonesia's Askeskin programme. Soc Sci Med. 2013;96:264-71.

6. Nugraheni WP, Hidayat B, Nadjib M, Pambudi ES, Kosen S, Trihandini I, et al. Impact evaluation of national health insurance toward access hospital inpatient care in Indonesia. Indian J Public Health Res Dev. 2018;9(2):196-200.

7. Thabrany H, Setiawan E. Report of the study on referral care. Jakarta: Universitas Indonesia; 2016.

8. Trisnantoro L, Hendrartini Y, Susilowati T, Meliala A, Kurniawan MF, Putra WDR. Skenario pelaksanaan kebijakan jaminan kesehatan nasional: apakah ada potensi memburuknya ketidakadilan sosial di sektor kesehatan? Studi awal dalam monitoring JKN di 12 propinsi: periode monitoring I: bulan Januari-Juni 2014 [Internet]. Yogyakarta: Pusat Kebijakan dan Manajemen Kesehatan, Fakultas Kedokteran, Universitas Gadjah Mada; 2014 July [cited 2021 May 30]. Available from: https://kebijakankesehatanindonesia.net/ images/2014/hasil-monev-jkn.pdf.

9. Peraturan Presiden Republik Indonesia Nomor 12 Tahun 2013 tentang Jaminan Kesehatan.

10. Aktariyani T, Endah EN, Rimawati, Aineka G. Laporan reviu kebijakan program jaminan kesehatan nasional (JKN): analisis dalam tiga aspek: kepesertaan, pelayanan dan pembiayaan [Internet]. Yogyakarta: Pusat Kebijakan dan Manajemen Kesehatan, Fakultas Kedokteran Kesehatan Masyarakat dan Keperawatan, Universitas Gadjah Mada; 2020 [cited 2021 May 20]. Available from: https://kebijakankesehatanindonesia. net/datakesehatan/file/Laporan-reviukebijakan-program-JKN.pdf.

11. Budiono A, Jati SP, Suryawati C. Evaluasi implementasi pelayanan jaminan kesehatan nasional pada Balai Kesehatan Paru Masyarakat (BKPM) wilayah Semarang terikat kerjasama dengan Badan Penyelenggara Jaminan Sosial (BPJS) Kesehatan. JMKI. 2016;4(1):74-82.

12. Putradi ADG, Adnan M, Kushandajani. Evaluasi program jaminan kesehatan nasional (JKN) di Kota Pekanbaru tahun anggaran 2014-2015. J Politic Gov Studies. 2015;5(4):311-20.

13. Ramdani AH, Setiawati EP, Herawati DMD. Persepsi dokter puskesmas di Kota Bandung terhadap implementasi sistem jaminan kesehatan nasional. JSK. 2016;1(4):171-8.

14. Rante H, Mutiarin D. Persepsi masyarakat terhadap layanan Badan Penyelenggara Jaminan Sosial Kesehatan di RSUD Morangan Sleman DIY. J Govern Public Policy. 2016;3(1):1-20.

15. Meutuah LD, Ishak S. Analisis kepuasan dokter spesialis terhadap program jaminan kesehatan nasional (JKN) di Rumah Sakit Umum Daerah dr. Zainoel Abidin tahun 2014. JKS. 2015;15(1):7-19.

16. Octavianugrah KE, Melialala A. Persepsi klinisi yang bekerja di RS Mitra Paramedika terhadap biaya paket INA-CBGs dan patient safety [thesis]. Yogyakarta: Universitas Gadjah Mada; 2016 [cited 2019 January 13]. Available from: http://etd.repository.ugm. ac.id/index.php?mod=penelitian_detail\&su $\mathrm{b}=$ PenelitianDetail\&act=view\&typ $=\mathrm{html} \& \mathrm{bu}$ ku_id=103577\&obyek_id=4. 2016.

17. Ghozali I. Aplikasi analisis multivariate dengan program IBM SPSS 21 update PLS regresi. $7^{\text {th }}$ Edition. Semarang: Badan Penerbit Universitas Diponegoro; 2013.

18. RSUD Al-Ihsan Provinsi Jawa Barat. Profil RSUD Al-Ihsan Provinsi Jawa Barat. Bandung: RSUD Al-Ihsan Provinsi Jawa Barat; 2021.

19. Trisnantoro L, Marthias T, Djasri H, Chandra, Hasri ET, Kurniawan MF, et al. Laporan hasil penelitian evaluasi kebijakan JKN di 13 provinsi Indonesia [Internet]. Yogyakarta: Pusat Kebijakan dan Manajemen Kesehatan, 
Fakultas Kedokteran, Kesehatan Masyarakat dan Keperawatan, Universitas Gadjah Mada; 2020 [cited 2021 May 30]. Available from: https://kebijakankesehatanindonesia. net/datakesehatan/file/Laporan-evaluasikebijakan-JKN-2020.pdf.

20. Peraturan Presiden Republik Indonesia Nomor 82 Tahun 2018 tentang Jaminan Kesehatan.

21. Badan Pengembangan dan Pemberdayaan SDM Kesehatan, Kementerian Kesehatan Republik Indonesia. Rasio tenaga kesehatan terhadap jumlah penduduk (per provinsi) per 100.000 penduduk [Internet]. Jakarta: Kementerian Kesehatan Republik Indonesia; 2021 [cited 2021 August 4]. Available from: http://bppsdmk.kemkes.go.id/info_sdmk/ info/renbut.

22. Susanti Y, Azis Y, Kusnadi D. Pengaruh appointment registration system terhadap waktu tunggu dan kepuasan pasien. GMHC. 2015;3(1):40-7.

23. Susanti Y, Irasanti SN, Akbar IB, Sukarya WS. Faktor affecting surgical waiting time in cancer patients at referral hospitals of West Java province. GMHC. 2020;8(2):118-25.

24. Zarei A, Arab M, Froushani AR, Rashidian A, Ghazi Tabatabaei SM. Service quality of private hospitals: the Iranian patient's perspective. BMC Health Serv Res. 2012;12:31.

25. Misnaniarti, Hidayat B, Pujiyanto, Nadjib M, Thabrany H, Junadi P, et al. Ketersediaan fasilitas dan tenaga kesehatan dalam mendukung cakupan semesta jaminan kesehatan nasional. JPPPK. 2017;1(1):6-16.

26. Prabhakaran S, Dutta A, Fagan T, Ginivan M. Financial sustainability of Indonesia's jaminan kesehatan nasional: performance, prospects, and policy options. Washington: Palladium, Health Policy Plus, Tim Nasional Percepatan Penanggulangan Kemiskinan (TNP2K); 2019.

27. Mcdonald SM. Perception: a concept analysis. Int J Nurs Knowl. 2012;23(1):2-9.

28. Rakhmat J. Psikologi komunikasi. Bandung: Remaja Rosdakarya; 2012.

29. Putri AE. Paham SJSN: sistem jaminan sosial nasional. Jakarta: Friedrich-Ebert-Stiftung; 2014.

30. Factors influencing perceptions [Internet]. 2009 September 17 [cited 2021 August 4]. Available from: https://www.citeman. com/7036-factors-influencing-perceptions. html. 